\title{
Intoxicated children at an intensive care unit: popular medicine risks, complications and costs*
}

\author{
Consuelo de Rovetto, MD¹, Sandra Concha, MD²
}

\section{SUMMARY}

Introduction: The Hospital Universitario del Valle (HUV) at the Pediatrics Intensive Care Unit (PICU) admits intoxicated patients, erroneously medicated by «teguas» or family members with serious aggravation of basic diseases or generating severe intoxications. Absent reports of these practices in Colombia motivated the publication of this case series

Objective: To report a series of pediatric intoxication cases secondary to oral or dermatological application of varied substances by healers («teguas») or family members, leading to admission at the PICU, and to describe complications and hospital costs of these events.

Methodology: Clinical charts of patients admitted to the PICU with diagnosis of exogenous intoxication during May 2001 to September 2004, were reviewed. Of 28 registered cases during that time, only 14 clinical charts were recovered. Variables evaluated included: age, gender, proceeding, administered substance, person responsible for the administration, complications, days of mechanical ventilation, total days at the intensive care unit and average costs. Of the 14 medical records with exogenous intoxications only 5 cases were involuntary and 9 were related to the administration of substances by quacks or family members; these are the ones reported in this series.

Results: We report a total of 9 intoxicated patients, 5 girls and 4 boys, with an age range from 1 to 24 months, all from Cali. Topical administered substances: alcohol 6/9, vinegar 1/9; oral: aspirin 2/9, paico 1/9, and unidentified herbs 1/9. Administered substances by teguas: 6 patients; 3 by family members. All patients had metabolic acidosis with an increased anion gap: 27 in average (range from 21 to 32). All required mechanical ventilation (2 to 32 day range). Average hospital day costs were \$6 657,800 pesos (around U\$3,000.oo). Three patients died and 4 presented acute renal failure, 2 convulsions, 2 nosocomial infections, 1 subglotic stenosis.

Conclusions and recommendations: Those practices are a high risk for children and have high health costs. Mortality and severe complications are high. Educational campaigns should be started in the community to prevent these cases.

Keywords: Intoxication; Children; Intensive Care Unit; Healer; Alcohol; Vinegar; Aspirin; Herbs.

Niños intoxicados en la unidad de cuidado intensivo: riesgos de la medicina popular, complicaciones y costos

\section{RESUMEN}

Introducción: A la Unidad de Cuidado Intensivo Pediátrico (UCIP) del Hospital Universitario del Valle(HUV) ingresan pacientes intoxicados, que antes han sido medicados de manera errónea por teguas o familiares con grave empeoramiento de las enfermedades de base o con intoxicaciones severas. La ausencia de informes sobre estas prácticas en Colombia motivó la publicación de esta serie de casos.

Objetivo: Informar una serie de casos pediátricos con intoxicaciones, secundarias a la administración oral o dérmica de sustancias administradas por curanderos (teguas) o familiares conducta que implicó hospitalización en UCIP, describir las complicaciones y sus costos hospitalarios.

Materiales y métodos: Se revisaron las historias clínicas de los niños que ingresaron a la UCIP del HUV con diagnóstico de intoxicación exógena, en el período de mayo 2001 a septiembre 2004. De los 28 casos registrados en tiempo sólo se recuperaron 14 historias clínicas. Se aplicó un formulario para obtener información de ellas que permitiera evaluar características socio-demográficas (edad, género, procedencia), tóxico administrado, persona responsable de la administración, complicaciones, días y costos de la hospitalización. De estas 14 historias, solamente 5 fueron intoxicaciones

* Poster work presented at the 24th Pediatrics Colombian Congress, Cartagena, June 2-5, 2005.

1. Chairman, Pediatrics Department, Medical School, Universidad del Valle, Cali, Colombia. e-mail: rovettos@gmail.com

2. Pediatrician, Universidad del Valle, Cali, Colombia. e-mail: sandra_concha@hotmail.com

Received for publication October 5, 2008 Accepted for publication July 1, 2009 
accidentales y 9 se asociaron con administración de sustancias por teguas o familiares, que son las que se comunican en esta serie.

Resultados: Se informa un total de 9 pacientes intoxicados, 5 de género femenino con rango de edad 1 a 24 meses todos provenientes de Cali. Las sustancias administradas fueron por vía tópica: alcohol, 6/9; vinagre, 1/9; por vía oral: aspirina, 2/9; paico, 1/9; y otras hierbas no identificadas, 1/9. La administración de las sustancias fue hecha por teguas en 6 pacientes, y en 3 por familiares. Todos los pacientes presentaron acidosis metabólica con brecha aniónica aumentada con promedio 27 (rango 21 a 32), todos requirieron ventilación mecánica (rango 2 a 30 días), el promedio de estancia en la UCI fue 12 días (rango 2-34 días), y el promedio de costos de hospitalización fue \$6’567,800. Murieron 3 pacientes, 4 presentaron falla renal aguda, 2 tuvieron convulsiones, hubo 2 infecciones nosocomiales, y 1 estenosis subglótica.

Conclusiones y recomendaciones: Estas prácticas tienen alto riesgo para los niños y costos a los servicios de salud. La mortalidad y las complicaciones son altas. Se deben emprender campañas educativas en la comunidad para prevenir estos casos.

Palabras clave: Intoxicación; Niños; Unidad Cuidado Intensivo; Curandero; Alcohol; Vinagre; Aspirina; Hierbas.

Ingestion of toxic substances is a common injury cause in small children, usually less than six years of age. In most cases agent ingestion is minimal and has no important clinical effects. However, in some cases the ingestion is a risk for patient's life and can produce severe neurological sequels in survivors and death in some ${ }^{1}$.

Reported incidents in toxicology centers are estimated in about 26\%. Even if preventive measures reduced frequency and severity of children intoxication, these are an important case of consult in emergency services ${ }^{1,2}$.

The most commonly ingested toxic substances include: cosmetics, cleaning products, analgesics, cough medicines, iron, pesticides, vitamins and hydrocarbons. Ingestion is usually accidental ${ }^{1,2}$.

"Curandero» (healer) is a used word in Latin America ${ }^{3,4}$ and it refers to the traditional role of «chamán» or «hierbatero», a character consulted by people for physical healing or to suppress the «mal de ojo» (evil eye), a superstition phenomenon where a person can damage another through looking at him. The healer usually uses herbs or potions as a part of the treatment.

A similar term "tegua» ${ }^{5}$ is a Colombian idiom going back to pre-Columbus times applied to a person who practices traditional medicine. Teguas were Colombian aborigines that during Spanish Conquest lived in the Boyacá region and became famous using plants as medicines; traditionally they had long lives and died with no disease. They disappeared during 19th century. At the beginning of 20th century that traditional role was renewed with the figure of José Domingo Muñoz, a Boyacá country healer from the village of Teguas (Macanal) who arrived to Bogotá to practice his «art» and became famous. Following traditional language people called him «Tegua», word that became familiar in Bogotá and later in Colombia to name all healers, who kept alive the popular beliefs of the indigenous past, and extending it to every medicine practitioner with no title ${ }^{5}$.

Today, teguas constitute a popular movement, culturally accepted, that many mothers choose as the first medical care option for their diseased children, without a clear knowledge of the risks. Prevalent popular beliefs such as «mal de ojo» ${ }^{6}$ favour children attention by those persons.

In Colombia, the abundance of empirical medicine doctors, such as curanderos and teguas, and easy access to them and lack of confidence in traditional medicine, favour in some cases children intoxication, by oral use of aspirin, herbs ${ }^{8,9}$ alcohol $^{10}$, or topical application of substances such as vinegar or alcohol.

In recent years at the PICU of HUV several patients have been evaluated with severe intoxication after consulting teguas or administration of toxic agents by family members, frequently to treat fever and other symptoms.

The purpose of this paper is to describe patients with external intoxications, alert community on risks caused by those consults and to implement educating measures concerned to dangers from these practices and treatments.

\section{MATERIAL AND METHODS}

Approval to obtain clinical charts from archives and review of ethics committee at HUV were obtained. Clinical charts were reviewed from patients registry admitted to the PICU at HUV with diagnosis of accidental or induced intoxication, from May, 2001 to September 2004. From 28 cases found in the registry, 14 charts 
were recovered and reviewed to complete the research questionnaire, done personally by the authors. Only 5 intoxications were accidental, 9 were associated to administration of substances by teguas or family members; these cases are the reported in this communication.

The analyzed variables, based in clinical history, were: age, gender, proceeding, intoxication cause and administration pathway, documented metabolic acidosis by blood gases and anion gap, mechanical ventilation days, hospital days, complications, and acute renal failure. Costs were calculated multiplying hospital days at the PICU by average days/hospital costs, depending if the patient was at intensive or intermediate care. Additionally if the patient received peritoneal dialysis, those costs were added.

\section{RESULTS}

Results are summarized in Table 1. From 9 reported patients 5 were girls, the age averaged 8.6 moths (from 1 month up to 24 months range). Associated substances to intoxication were: 1 ketone, 6 alcohols, 2 aspirin, 1 vinegar, 1 paico and 1 herbs used by teguas. Main administration path was: oral in 7 patients, combined topic and oral in 3 patients, only topic in 2 . Substances were given by teguas in 6 cases and by family members in 3. Metabolic acidosis with diminished bicarbonate and increased anion gap averaged 27 (21 to 32 range) was seen in all cases. Average ventilation days was 11.8 (2 to 30 range). Staying at the PICU in average was 12 days (2-34 range). Average hospital cost was \$6’567,800.

Other complications were acute renal failure in 4 patients, 2 of them required peritoneal dialysis; convulsions in 2 patients, nosocomial infections in 2, subglotic stenosis due to prolonged tracheal intubation in 1 patient. Three patients died and mortality was 33\% of found cases.

\section{DISCUSSION}

Even in this century healers and teguas keep being one option which mothers use frequently, looking to solve their children health problems. These persons use toxic substances like alcohol, oral or topic, or a combination of vinegar and different herbs, such as paico ${ }^{1,8,9}$ for any children as unique treatment for symptoms.
It is alarming to find from revised hospitalized PICU intoxication children, 6 were by teguas administered substances, and 3 by family members. On literature review of intoxications, we found no reports of similar cases, which motivated publication of this paper.

If we consider these histories revisions were only from patients admitted to UCI, the low clinic chart recuperation of intoxicated patients, this practice dimension might be higher when we study children admitted to the emergency service; with the cultural frequency those practices have, one should ask routinely this background in children with metabolic acidosis suggesting exogenous intoxication.

The intense preoccupation to lower fever in children induces the topic application of alcohol and/or vinegar, which are still a very frequent practice in our media, despite knowing that these substances might be absorbed through the skin. Educational campaigns to reduce their topic use are not sufficient and should be reinforced. One should emphasize that physical media to decrease temperature should be done with lukewarm water only. Aspirin use limited to certain conditions in children, is not the election drug any longer to manage fever in children, and it was found in 2 cases.

Total case number in this series are less than 2 yearold, suggesting that the lactating babies might have greater risk for this type of intoxications.

If clinical history orientates to this diagnosis, adequate blood and urine samples should be taken to analyze by toxicology, confirm diagnosis and rapidly establish treatment. If skin application background is present, skin wash should be done ${ }^{1}$.

In our series, diagnosis was done with clinical history, family members questioning and laboratory confirmation of metabolic acidosis with an elevated anion gap.

Quantification of metabolic acidosis with anion gap mediation keeps being a fast and easy way in an emergency service to determine probable exogenous intoxications, besides being an important predictor of severity and mortality in those patients, once diagnosis have been confirmed $^{7}$. In this series, the 3 death patients had anion gap of 25 and 32.

These intoxications imply elevated costs for health services, as shown in present study, all patients implied admission to the intensive care unit; the longer the stay, the higher the costs.

Total cases had severe complications as shown in 


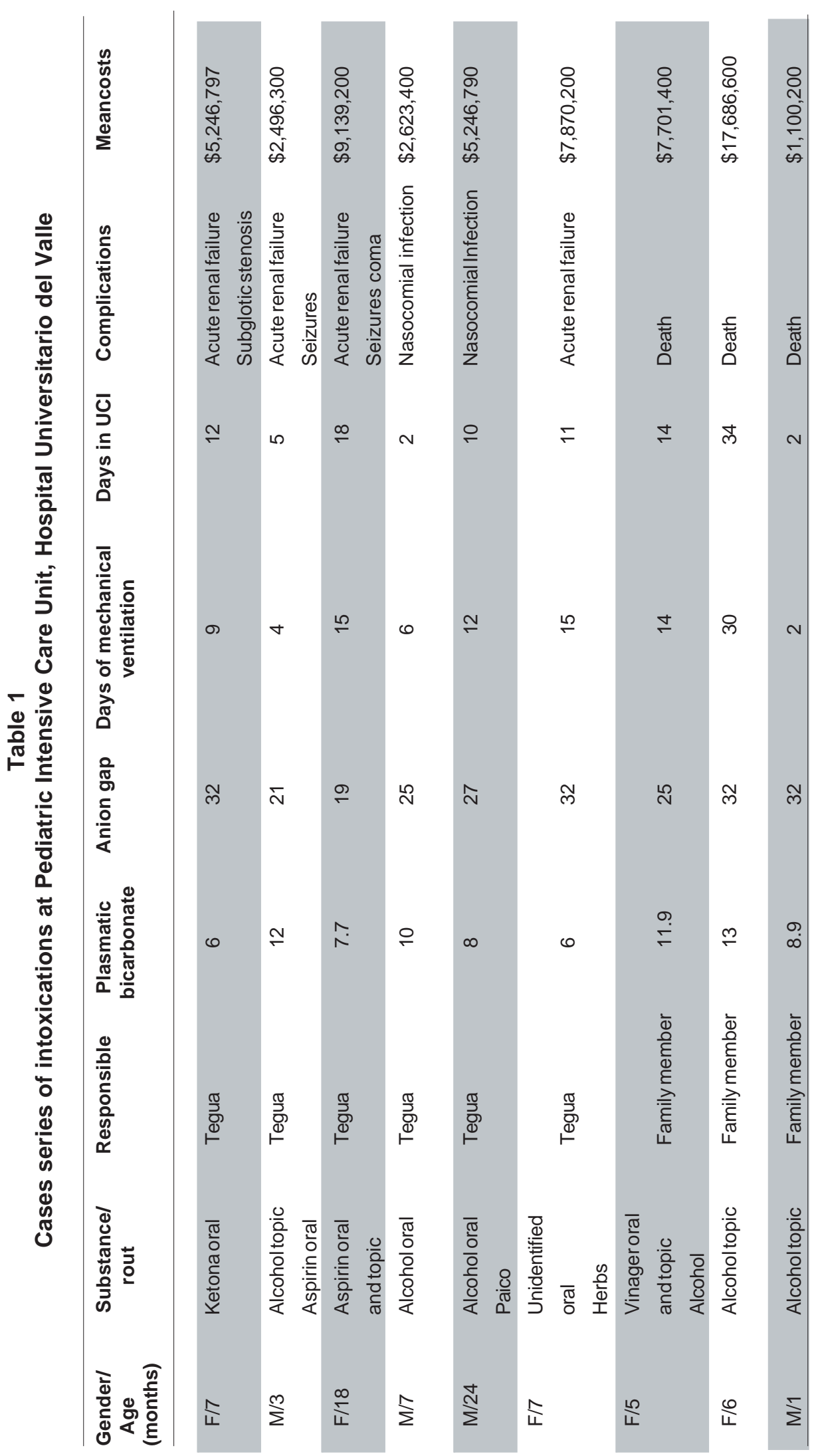

Table 1. Paediatric mortality of $33 \%$, in this series is very high considering it is due to preventable causes. This impliesurgent large preventive measures on community education and to make parents conscious of dangers in these practices settled in popular culture. Additionally, larger legal control and training for these medical empiric persons should be done.

Confirmation should be evaluated by toxicology tests, so it is fundamental an early suspicion of intoxication. The development of toxicology laboratories to back clinician and confirmation of toxic type are fundamental to optimize the treatment of these patients, allowing an early use of newer dialysis techniques, more effective than current peritoneal dialysis for toxic removal.

In the III Meeting on Indigenous Peoples and Ethnic Groups Commissions, of Latin American Parliament, in 2005 Brasil $^{11}$, where Traditional and Complementary Medicine (TCM) was debated, considered part of cultural patrimony ofpeople with knowledge transmitted by generations and transmitted by community mechanisms, proposed to incorporate in national health systems, when adjusted to legal norms stimulating a rational integrated use to national health systems. It was proposed to legislate and regulate the TCM; promote, protect, improve and preserve TCM knowledge and 
to establish TCM centres supervised by World Health Organization.

In Colombia, the 1164 law of 2007 purposed to establish dispositions of planning, formation and watching the development of human talent in health ${ }^{12}$. Article 19 said that alternative medicines may subsist with legally recognized academic certification by state and requiring an Unique National Registry. Article 20 approves respect and exercise of Traditional Medical Cultures, of diverse ethnical groups that may only be practised by recognized members of these cultures, according to their social regulation mechanisms.

In this context of Latin-American and Colombian laws, the government should establish a registry for healers and/or teguas; verify their capabilities and if necessary, to complement it so that they learn the risks of these topic and oral therapies for children in order to prevent new cases.

\section{CONCLUSIONS AND RECOMMENDATIONS}

Learned cultural standards make parents or family members, searching to improve their children's health, to consult teguas and curanderos, who offer them «salvation beverages» with risk for children's health and in many cases to cause intoxications that leave sequels or even death.

These practices, so popular in our media, imply a risk for pediatric population. Healers, teguas and curanderos should be capacitated about risks of intoxication and complications of these practices that are deleterious for children's health.

Topic substances administration such as alcohol and vinegar to lower fever, and the use of aspirin, are erroneous and imply a rather high risk of toxicity. The false belief that «all natural things are good», adds risks of intoxication with herbs and plants for children and adults.

Educational campaigns in schools, health centers and rural areas in Colombia should be established; massive communication media should inform this situation, giving mothers clear norms for opportune consultation to health entities when children are sick. Physical media to reduce temperature should be done only with lukewarm water and not alcohol or absorbed substances through the skin.

In medical education, it is important to know those cultural practices for a better education of parents and to suspect clinical cases.

A higher confidence among community for health services should be given so they become the first option for sick children.

We recommend to carry out a retrospective study in different paediatric hospitals in Colombia, to evaluate the true dimension of the problem.

\section{REFERENCES}

1. Roa JA. Enfoque del paciente intoxicado. In: Roa JA. Emergencias y urgencias en toxicología. $2^{\mathrm{a}}$ ed. Cali: Editorial Catorse; 1996. p. 1-7.

2. Leikin BJ, Paloucek FP. In poisoning and toxicology handbook. $3^{\text {a }}$ ed. Washington, DC: Lexi-Comp Inc.; 2002.

3. Curandero. (Recovered in August 13, 2006). Disponible en: www. es.wikipedia.org/wiki/Curandero

4. Maduro R. Curanderismo and Latino views of disease and curing. West J Med. 1983; 139: 868-74.

5. Tegua. (Recovered on July 10, 2009). Disponible en: www. saludcolombia.com/actual/salud4/novedad14.htm

6. Mal de Ojo. (Recovered in 24 Sep 2007). Disponible en: www.es.wikipedia.org/wiki/Mal_de_ojo

7. Hoffman R. Diagnostic testing and physical assessment: Laboratory testing. In: Erickson TB, Ahrens WR, Aks SE, Baum CR, Ling LJ. Pediatric toxicology: Diagnosis and management of the poisoned child. Chicago: McGraw-Hill; 2005. p. 151-9.

8. Roa JA. Plantas tóxicas. In: Roa JA. Emergencias y urgencias en toxicología. $2^{\mathrm{a}}$ ed. Cali: Editorial Catorse; 1996. p. 119-24.

9. Albino N, Tejo ME, Fernández ME. Comisión del Área Toxicología del Programa Nacional de Garantía de Calidad de la Atención Médica y el Programa de Prevención y Control de Intoxicaciones del Ministerio de Salud de la Nación. República Argentina. Plantas usadas en medicina popular. En: Manual de atención primaria de intoxicaciones. Parte especial; 2002. p. 197-202.

10. Litovitz T. The alcohols: ethanol, methanol, isopropanol, ethylene glycol. Pediatr Clin North Am. 1986; 33: 311-23.

11. Arregui R. Informe de III Reunión de la Comisión de Pueblos Indígenas y Etnias del Parlamento Latinoamericano. São Paulo, Brasil, May 2005. (fecha acceso mayo 20 de 2009). Disponible en http://www.diputados.gub.uy/Art104/2005/E0003.htm com

12. Ley 1164/2007 de 3 octubre, de Talento humano en salud. Diario Oficial Congreso de Colombia. Año. CXLIII. N ${ }^{\circ}$ 46771. 4-10- 2007. p. 3. 